\title{
HEBREWS' ANGELOLOGY IN THE LIGHT OF EARLY JEWISH APOCALYPTIC IMAGERY
}

\author{
Gert J. Steyn \\ University of Pretoria, Pretoria
}

\begin{abstract}
Hebrews' references and allusions to angels are investigated in the light of early Jewish apocalyptic imagery and against the backdrop of similarities with a number of aspects that possibly underlie the Qumran community. It became clear that the author of Hebrews has a complex and more developed understanding of angels. Firstly, the author presents a "high" Christology in Heb 1-2, which argues about Christ's exaltation to the right hand of God, a position as King and Judge that differs from the other "sons of God," i.e. the angels (1:4-5). As they have inferior positions, roles and names, the angels should worship this "Firstborn" (1:6). They are made to be winds, flames of fire, servants (1:7) and messengers of God to humanity (2:2). After his temporary humiliation (2:7), Christ now rules whereas the angels are still carrying out their duties through the aeons as servants of God. Secondly, Heb 12-13 takes the reader into heaven and presents an apocalyptic glimpse of a festal gathering of earthly believers and angels in the heavenly Jerusalem, sharing in an act of cultic worship within the "congregation of the Firstborn." Thirdly, the character of Moses as a "son of God" (Heb 3) and that of Melchizedek (Heb 7), who was perceived as the archangel Michael in some circles of early Judaism, were positioned alongside the angels by the author of Hebrews. His angelology is clearly subordinate to his Christology - a picture which becomes even clearer against the backdrop of the position of angels in the early Jewish apocalyptic world. Fourthly, Christian hospitality is based on the argument that those entertained might even be angels. The appeal is rooted in the belief of the visitation of angels amongst humans in an anthropomorphic form which makes them unrecognizable to humans. This argument completes the circle of relations between Christ, the angels and humans in Hebrews: Christ occupies the ultimate position in heaven and the angels are subordinate to him. Angels are nonetheless of a higher rank than humans, being the messengers of God.
\end{abstract}




\section{Introduction}

Explicit references to angels in Hebrews are to be found at the beginning (Heb 1-2) ${ }^{1}$ and at the ending of the book (Heb 12,13). But also the references to Moses and Melchizedek might have recalled known traditions which also viewed them as angelic figures. This prominence to the place of angels in relation to early Christianity comes as no surprise in this book as the later New Testament literature tends to pay more attention to angels than the early New Testament literature (Steyn 2003:1107-1128). The place of angels in the community to which the unknown author wrote, must have been significant if he opens his document with such a strong distinction between the angels and the Son - thus putting Christology into perspective. Scholarship struggles, however, to make sense of this role which angels held in the community to whom the document was intended as well as to the author's own perception and belief with regard to angels. Several suggestions were made, for instance:

(a) Gnostic influence. Käsemann (1961), Grässer (1965), Theissen (1969) and Thompson (1981) were more inclined to explain the prominence in Hebrews in terms of variations of a gnostic motif, but there is a strong case to be made against this direction (Lane 1998:cix).

(b) Angel worship. Yadin and others were of the opinion that the community was engaged in angel worship. Scholarship remains skeptical about this viewpoint, mainly due to the lack of sufficient evidence in this regard.

(c) Merkabah mysticism. Lane (1998:cviii-cix) and Guthrie (2004:425) observed that the study of the connection between the conceptual background of Hebrews, and that of Jewish Merkabah mysticism, could be traced back to Schenke (1973:433434) and to Williamson (1975-76:232-237). This opinion too, is viewed with skepticism.

(d) Comparison of the exalted Christ with the highest figures in Judaism. Recent commentators on Hebrews (e.g. Ellingworth, Lane; Attridge; et al) were more inclined to take the position that angels simply function as a mere comparison and rhetorical argumentation by the author and that not much more should be ascribed to their presence in this book.

(e) Rivalry between angels and humans. This viewpoint has recently been proposed by Georg Gäbel (2007:357-376). He is of the opinion that Hebrews talks about angels because "it determines Christ's relationship with God as well as his relationship with humans in contrast to the angels" (2007:372). Hebrews' exposition on angels is then, in Gäbel's opinion not a polemic against angel worship. Although he acknowledges the importance of angelomorphic motives for early Christology, he believes that such motives hardly occur in Hebrews (2007:358).

(f) Angel Christology. I suggested earlier that at the background of this opening argument about the place of angels as inferior beings alongside Christ, lies perhaps 
a skewed Christology - one in which a wrong understanding of Christ might have been present in this receptor community. Christ was probably understood to be simply "another son of God", i.e. an angel. The problem might thus not be angel worship, but rather an underlying angel Christology (Steyn 2003:1107-1128).

Still maintaining my position on some form of angel Christology, the place of angels in the book of Hebrews will be further investigated systematically in this study in the light of early Jewish apocalyptic imagery. ${ }^{2}$ Given the fact that Hebrews' angelology shows similarities with a number of aspects that possibly underlie the Qumran - or an Essene - community, this corpus of fragmented literature ought to be kept in mind as well. ${ }^{3}$ Interesting, for instance, is the sequence of themes found in Hebrews 1-7, which have striking parallels with the sequence of the first three Sabbath Songs of the Shirot 'olat ha-Shabbat (4Q400-407; 11Q17). ${ }^{3}$ The first song deals with God's appointment of an angelic priesthood in heaven - note Heb 1-2 and Christ's difference from the angels. The second song deals with the Torah, theophany, and the heavenly and earthly communities - note the issue of the law that was given by angels to Moses and Moses' own position in relation to Christ (Heb 2; 3:1-6). The third song deals with the number seven and with Melchizedek - note the references to Melchizedek and his place in relation to Christ (Heb 7).

In keeping with the focus of this study, though, Hebrews' references and allusions to angels will now be systematically investigated in the light of early Jewish apocalyptic imagery. In the first part below, Hebrews 1-2 comes under investigation. These two chapters argue about Christ's exaltation, his position on the throne at the right hand of God, and that Christ is superior to the angels in terms of his Name (1:4-5) and his position in heaven. In his exalted position, the angels should worship this "Firstborn" (1:6), they are made to be winds, flames of fire, servants (1:7) and messengers of God to humanity (2:2), that Christ was made lower than the angels (2:7) is to be understood in light of his humiliation during the time that he came down to earth. In the second part, Hebrews 12-13 takes the reader into heaven and presents an apocalyptic glimpse of a festal gathering of earthly believers and angels in the heavenly Jerusalem, sharing in an act of cultic worship within the "congregation of the Firstborn." In the third part, reference will be made to the possibility that the characters of Moses (Heb 3) and Melchizedek (Heb 7) were also understood to be angels by some early Jewish groups. The fourth part of this study briefly discusses Christian hospitality based on the argument that those entertained might even be angels.

\section{Christ's Superiority above the Angels (Heb 1-2)}

The angelology of Hebrews cannot be detached from its advanced Christology. Angels are being "put in their place" at the opening of the document. In contrast to 1 Enoch, "Hebrews does not distinguish between angels and other created supernatural forces, 
nor between different classes of angels" (Ellingworth 2000:120). The author makes it clear that Christ sat down at the right hand of the Majesty after he made purification for sins (Heb 1:3,13). This is achieved by quoting Psalm 2:7 at the beginning of the catena of quotations in Hebrews 1:5 and Psalm 109:1 (LXX) at the end of the catena in Hebrews 1:13. Presenting Christ in this manner as superior King to the angels, the unknown author of Hebrews equals Christ with God himself, because the Jewish Scriptures already assigned a place to the angels that is subordinate to God (cf. Job 1:6; 2:1; 38:7; Pss 29:1; 82:6; 89:6; cf. Deut 32:43 LXX).

\subsection{Christ's Name is Superior to that of the Angels (Heb 1:4-5)}

Christ's superior position in comparison to that of the angels is clear from a number of

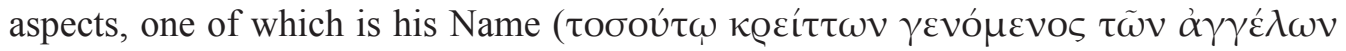

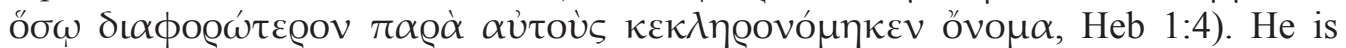
called "Son" by the "Father" according to the quotations from Psalm 2:7 and 2 Samuel 7:14 in Hebrews 1:5, although this in itself might not be different from the angels as they were also known as "sons of God" - a concept that was eventually fused with the concept of angels and a development already present in Daniel 3:25 and reflected in the LXX (Newsom 1992:155-156). The difference between Christ and the angels probably lies thus in the Father's institution of the Son as a royal supreme King and Judge on God's throne.

1QM 12.1-4 provides some interesting insight into the relation between the Name of God and the names of the angels: "The host of the Angels is in thy holy abode, praising thy Name... [The list] of the names of all their host is with Thee in the abode of thy holiness. Thou hast recorded for them, with the graving-tool of life" (Vermes 1977:139). According to Jewish tradition, the names of the angels came from Babylon. In the Jewish mind, God had receded to an immeasurable distance by this time and the angels helped to fill the gap between God and humanity (Wilson 1930:135). They brought the realm of God closer to humanity and took responsibility for certain functions which were often closely connected to the meaning of their names. The issue of the names of the angels was especially important for the Essenes according to Josephus (B. J. 2.142) (so also Beckwith 2005:37). Without implying Essene origins, it is especially 1 Enoch ' ${ }^{4}$ so-called "Book of the Watchers" (1 En 1-36) that gives us a glimpse of the importance of knowing the names of the angels in an apocalyptic context. Chapter 20, for instance, lists the names of the archangels. But also other passages in 1 Enoch make reference to this: "I came to know their names, which the angel who came with me revealed to me" ( 1 En 40:2); "And I saw other lightning and the stars of heaven. And I saw how he called them each by their (respective) names, and they obeyed him" (1 En 43:1).

Apart from the references to the names of the angels, 1 Enoch also testifies to the revelation of the "Name of the Son of Man" in which salvation takes place: "...he has preserved the portion of the righteous because they have hated and despised this world of oppression (together with) all its ways of life and its habits in the Name of the Lord 
of the Spirits; and because they will be saved in his Name and it is his good pleasure that they have life" (1 En 48:7); "...the Name of that (Son of Man) was revealed to them" [B and C interpolate: "And he sat on the throne of his glory; and the presidency [lit. 'head'] of the (final) judgment was given unto the Son of Man" (1 En 69:27).

When studying the names of the angels in 1 Enoch, it is noteworthy that "several names emphasize God's judicial activity" and that "the names help to identify the conspirators and give some sense of the authority and the scope of the conspiracy" (Nickelsburg and Baltzer 2001:181).

\subsection{Christ's Position in Heaven is Different than that of the Angels}

Christ's position on the throne of God as God's Son is elevated and superior to that of the angels as the other "sons of God" whose subordination, in turn, is clearly pointed out in the quotation from Ode 2:43 LXX (that is, Deut 32:43 LXX): "Let all the angels worship him." This apocalyptic imagery is known in other earlier Jewish literature. In a reconstruction of part of a hymn amongst those of 1QH $25.35-26.10$, The Hymn of the Exalted One, an unidentified figure asks: "Who is like me among the angels (literally 'gods')?" - resembling the biblical question addressed to God: "Who is like you among the angels?" Wise (2000:n.p.) draw attention in this regard to the "obvious comparison to NT statements about Jesus and to the NT use of divine language from the OT to describe him. Moreover, the figure is, like the Jesus of Hebrews, "seated on a throne at the right hand of God." Also a number of passages in 1 Enoch present similar imagery when the "Elect One," the "Son of Man" sits on the throne of glory: "In those days, (the Elect One) shall sit on my throne, and from the conscience of his mouth shall come out all the secrets of wisdom, for the Lord of the Spirits has given them to him and glorified him... And the faces of all the angels in heaven shall glow with joy, because on that day the Elect One has arisen (1 En 51:3-5); “... says the Lord of the Spirits: 'You have to see my Elect One, how he sits in the throne of glory and judges Azaz'el and all his company, and his army, in the name of the Lord of the Spirits" (1 En 55:4); “... and pain shall seize them when they see that Son of Man sitting on the throne of his glory" (1 En 62:5); “... him who has been concealed. For the Son of Man was concealed from the beginning, and the Most High One preserved him in the presence of his power; then he revealed him to the holy and the elect ones. The congregation of the holy ones shall be planted, and all the elect ones shall stand before him" (1 En 62:6-8).

\subsubsection{All God's Angels Should Worship the "Firstborn" (Heb 1:6)}

The interesting textual differences between Deuteronomy 32:43 in the MT (where the

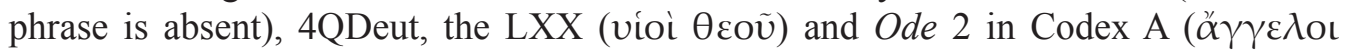
$\theta \varepsilon \delta \tilde{v})$ have already been pointed out several times before in secondary literature (cf. Steyn 2000, 2007; Karrer 2006; McLay 2003, 2006).

Still being part of Christ's institution or appointment as Ruler by God himself is the

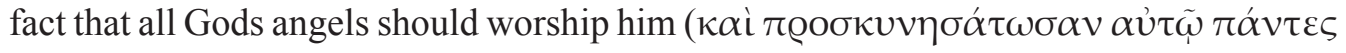




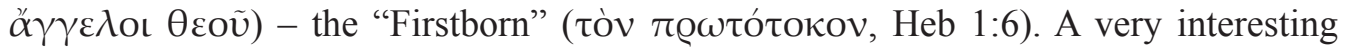
hermeneutical key for understanding Hebrews is to be found here in the use of the term

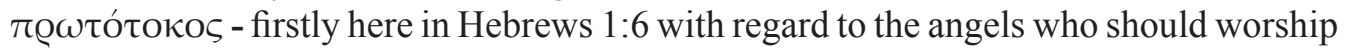
the "Firstborn", but also later in Hebrews 12:23 when the community for whom the document was intended "has come to... the assembly of the Firstborn who are enrolled

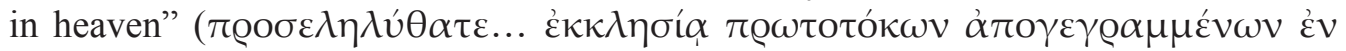
oủoavoĩs). The underlying cultic tone of the book surfaces clearly in two "assemblies of the Firstborn" in Hebrews. The first assembly, those whom Jesus calls "brothers" ( $\dot{\alpha} \delta \varepsilon \lambda \phi o u ̀ \varsigma \alpha u \dot{\tau o u ̀ ~} \kappa \alpha \lambda \varepsilon \tilde{\imath} v$, Heb 2:11) is referred to when Jesus proclaims the Name of His Father in the midst of the "congregation" ( $\dot{\varepsilon} \nu \mu \varepsilon \dot{\varepsilon} \sigma \omega \dot{\varepsilon} \kappa \kappa \lambda \eta \sigma i \alpha \varsigma \dot{v} \mu \nu \eta \tilde{\sigma} \sigma \sigma \varepsilon)$ in Hebrews' "Jesus-saying" (Steyn 2001:433-440) from Psalms 21:22 (LXX). This assembly consists of the believers on earth. The second assembly, however, is the heavenly "assembly of the Firstborn" and consists of "thousands upon thousands of

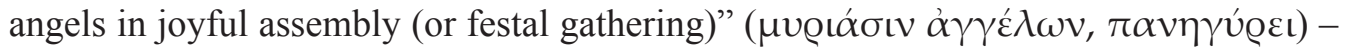
now being joined by Hebrews' community who "came to," or arrived, at this assembly in heaven. It is against the backdrop of the so-called "Angel Liturgy" that the parallels with Hebrews are striking. Consisting of 13 Sabbath Songs for use in one quarter of the year and used for liturgical rites, the Angel Liturgy presents a sequence of events in which the community ${ }^{5}$ started their worship on earth, believing that their worship rite ends with the angels in heaven. However, the idea remains controversial and difficult to prove beyond doubt in Hebrews.

\subsubsection{Angels are made to be winds ( $\pi v \varepsilon v ́ \mu \alpha \tau \alpha)$ (Heb 1:7)}

The quotation from Psalm 103:4 (LXX) ${ }^{6}$ in Hebrews 1:7 forms a key aspect for the author of Hebrews' argument ${ }^{7}$ about the subordinate place that angels are taking in relation to Christ and "their dependence on God" (Ellingworth 2000:116). Quoting these words, the author of Hebrews elaborates particularly on the nature of the angels. There are two clear traditions (probably due to the rabbinic traditions regarding the mutability of angels $)^{8}$ that can be identified here and which are due to the interchange or switching of the subjects: 9 (a) God makes "the winds his messengers ${ }^{10}$ and flames his servants." This version is followed by the MT. ${ }^{11}$ Also $1 \mathrm{QH} 1.10-12$ takes the same approach by praising the unlimited possibilities of the Creator who could even use the natural elements as his messengers (Grässer 1990:81). (b) God makes "the angels winds and his servants flames of fire." This is followed by the LXX, ${ }^{12}$ Targum Jonathan (Schröger, 1968: 58) and Hebrews. The Syrian and other eastern versions of 2 Esdras (4 Ezra) 8:21 follow a similar direction by referring to the angels who "are changed to wind and fire" (Bruce 1985:18). Also the interpretation in the Latin version of this passage refers to the angels "whose service takes the form of wind and fire" (Bruce 1985:18). ${ }^{13}$ The quotation highlights their transformation by God into two kinds of entities or elements, namely

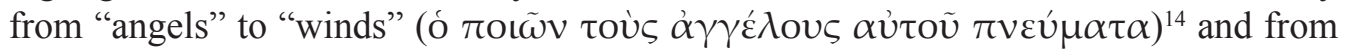

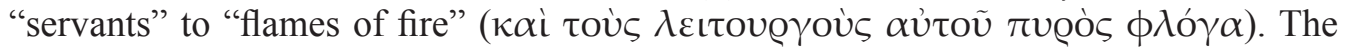


point of the argument is then that the angels are agents used by God in his service. They are transformed and sent by God on his demand. The Son, however, takes his position on the royal and judicial throne. He rules with God, whereas the angels are mere agents used by God in his service.

Ancient philosophers understood the basic components, or "elements," of the physical world to be earth, air, water, and fire. ${ }^{15}$ It is thus not strange that also in the apocalyptic world there were angels who were related to the elements of wind (cf. Rev 7:1), fire (cf. Rev 14:18) and water (cf. Rev 16:5). They were sometimes presented to be in charge of the elements, and at other times the elements themselves were identified as angels. ${ }^{16}$ Several passages probably imply that the winds are angels, although different

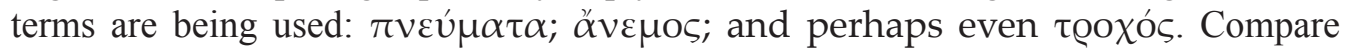

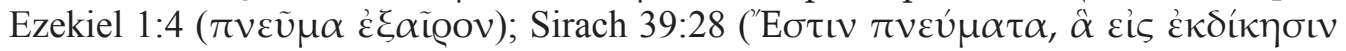
हैं $\tau \iota \sigma \tau \alpha \iota)$ ) Psalm 17:11 (LXX) refers to the Lord who "came swiftly upon the wings of

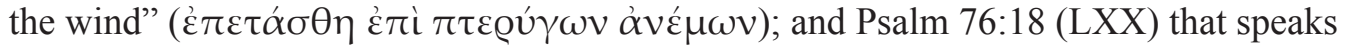

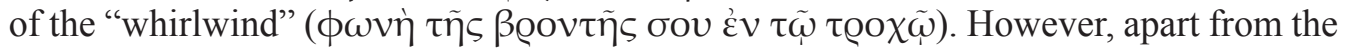
Magical Papyri that refer explicitly to "the angels of the winds," 17 also 1 Enoch refers to "The frost-wind (that) is its own guardian and the hail-wind is a kind of messenger/ angel" ( 1 En 60:17). Especially the parallel structure of 1 Enoch 14-16 and 1 Enoch 17-19 is interesting in this regard where Enoch is taken on a journey to God's throne (Nickelsburg and Baltzer 2001:277). In 1 Enoch 14:8 "the winds were causing (him) to fly and rushing (him) high up into heaven" where he approached a wall "built of white marble and surrounded by tongues ${ }^{18}$ of fire" (vv.9, 12). In 1 Enoch 17:1, Enoch is "lifted up into one place where there were (the ones) like the flaming fire" - and where Uriel showed him around during his throne vision (1 En 19:1).

\subsubsection{Angels are made flames of fire ( $\pi$ voò $\$ \lambda \lambda$ ó $\gamma \alpha$ ): reflecting the glory of God (Heb1:7)}

The same quotation from Psalm 103:4 (LXX) also states that the angels are made "flames of fire" by God. It was especially Uriel, the angel who instructed Ezra (2 Esd $4: 1 ; 5: 20 ; 10: 28$ ) and who was "over the world and Tartarus" (cf. 1 En 19:1; 20:2 [in the Greek version]), who was known as the "fire" or "flame of God" (Beckwith 2005:35). Revelation probably stands in the same tradition when it refers to the "mighty angel who came down from heaven... his face like the sun, and his legs like pillars of fire"

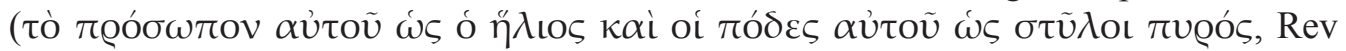

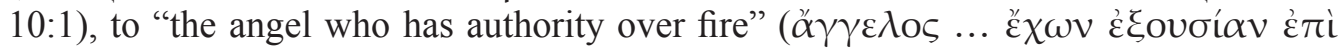

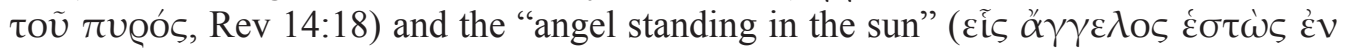
$\tau \tilde{\omega} \eta \dot{\eta} \lambda \hat{i}(\omega, \operatorname{Rev} 19: 17)$.

The book of 3 Enoch, although claiming to have been written prior to the death of Rabbi Ishmael shortly before the Bar Kochba war of 132 C.E., most probably dates much later (Alexander 1983:225-226). It, nonetheless, provides vivid imagery of the Jewish apocalyptic world and stands in a similar apocalyptic tradition, speaking of "the 
ministers of consuming fire" ( 3 En 6:2) and "those who cleave the flames" ( 3 En 6:2; 15:2) - the latter being a name that comes from Psalm 29:7 and found in the early liturgical poets (Alexander 1983:261). Cf. also 3 Enoch 36:1-2: “...the River of Fire... flows out from beneath the throne of glory..." and "All the ministering angels first go down into the River of Fire and bathe themselves in the fire of the River of Fire..." In Ezekiel 1:4 reference is made to "a great cloud with brightness around it and fire flashing forth continually, and in the middle of the fire, something like gleaming amber." In Daniel 3:25, after Shadrach, Meshach, and Abednego were thrown into the fire, there were four men walking unbound in the middle of the fire, unhurt, "and the fourth had

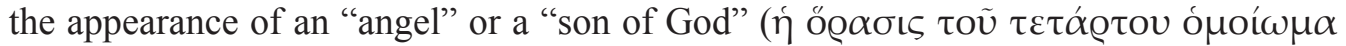

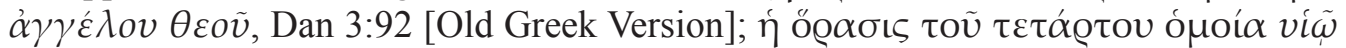

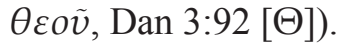

The bright shining light of God's presence is described in passages like Ezekiel

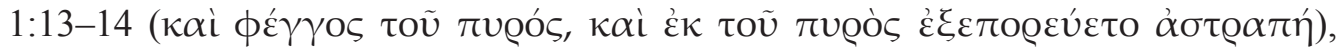

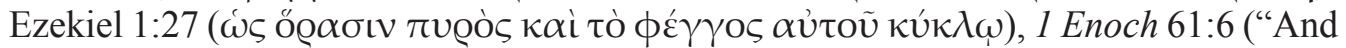
those who are in heaven above and all the powers received a command - one voice and one light like fire"), and in 1 Enoch 71:1, 2: ("And I saw the sons of the holy angels walking upon the flame of fire... I saw two rivers of fire, the light of which fire was shining like hyacinth"). God's fiery throne, in turn, is described in Daniel 7:9-10 (ó

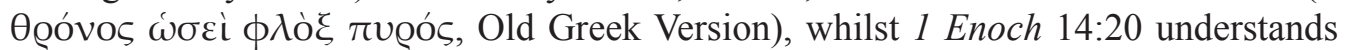
God sitting on the throne as "the Great Glory (who) was sitting upon it." Hence, the idea of angels reflecting the glory of God was a common concept in antiquity. To be in the presence of God's $\delta$ ó $\xi \alpha$, means that the angels would reflect this glory of God. The angels carried the "flaming fire" ( $\pi \tilde{v} \varrho \phi \lambda \varepsilon \dot{\gamma} O v)$ of God's glory that he has shown on Mount Sinai (Exod 24:17) (Ellingworth 2000:121; Karrer 2002:136) - later reinterpreted by Luke in Stephen's speech: "an angel appeared to him in the wilderness of Mount Sinai, in the flame of a burning bush" (Acts 7:30). Further traces of this can be seen in NT passages where angels appeared on earth, e.g. "Then an angel of the Lord stood before them, and the glory of the Lord shone around them" (Luke 2:9), and "His appearance was like lightning" (Matt 28:3).

The same intention probably lies behind 1 Enoch 108:12 ("I shall bring them out into the bright light, those who have loved my holy name"); Matthew 13:43 ("Then the righteous will shine like the sun in the kingdom of their Father") and Acts 6:15 ("and his face was like the face of an angel").

There is a difference, though, between the angels that are "flames of fire" (1:7) and the Son who "radiates" the glory of God (1:3). The angels are merely transformed ( $\pi \mathrm{ol} \tilde{\omega} v)$ into flames by God and reflect the glory of God, whereas the Son is "the

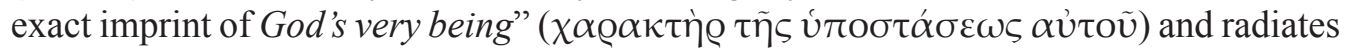
God's light himself in Hebrews 1:3. The latter concept is also echoed in John 5:35 of Christ: "He was a burning and a shining light: and you were willing for a season to rejoice in his light." The relation between the glory of God, the Son and the angels as serving agents becomes clear from passages such as the following: 
- Matthew 16:27: "For the Son of Man is to come with his angels in the glory of his Father" (par. Mark 8:38);

- Matthew 25:31: "When the Son of Man comes in his glory, and all the angels with him, then he will sit on the throne of his glory";

- Luke 9:26: "when he comes in his glory and the glory of the Father and of the holy angels."

\subsubsection{Connections between Angels and Stars}

Speculation between the heavenly bodies and angels was rife during Second Temple Judaism. The link between the angels and the stars - with "astral or at least starlike eschatological glory" (Nickelsburg and Baltzer 2001:558) - may be noted in passages such as Job 38:7; Psalm 148:1-4; Daniel 12:3:19 2 Baruch 51:10; ${ }^{20}$ Testament of Moses 10:9; Wisdom 3:7; 1 Enoch 104:2; and an extremely close connection in 1 Enoch 82:420 (Collins 1993:393-394). Stars are also an image for the "watchers" (1 En 86:1$3)$. No wonder that "it is an angel who conducts Enoch round the heavens above and explains to him the movements of the heavenly bodies that govern the year ( 1 En 72:1; 75:3-4; 78:10; 79:6; 80:1; 82:7-8)" (Beckwith 2005:35) and that he was shown "all the reservoirs of the stars and the luminaries - from where they come out (to shine) before the faces of the holy ones" (1 En 71:4).

Nickelsburg pointed out that there are sixteen compounds with - 'el in 1 Enoch, of which only two indicate functions of God (judge and creator, $7 ; 10$ ). All the others, with only one exception, "are linked in their first element with astronomical, meteorological, and geographical phenomena" (Milik 1976:29; Knibb 1978:70; Black 1970:123). "The names are of obvious relevance in the Enochic tradition with its interest in cosmology and astronomy and its frequent association of the elements and the angels in charge of them" (Nickelsburg and Baltzer 2001:178). There is, for instance, reference in 1 Enoch

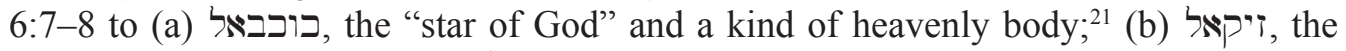
"shooting star of God"; and (c) ברקאל, the "lightning of God" (Nickelsburg and Baltzer 2001:181). The list of names imply that these...

... are high angels in charge of the orderly functioning of the heavenly and earthly phenomena: in heaven, not Uriel to be sure, but the angels over sun, moon, stars, shooting stars, thunder, and lightning; on earth, the angels in charge of sea and mountains, as well as the crucial rainy season and its clouds and rain. At the same time, the list lacks names associated with many other cosmic, meteorological, and geographic phenomena, and the total of two hundred angels is a small part of the thousands that a text such as 82:4-20 associates with the stars alone (Nickelsburg and Baltzer 2001:181).

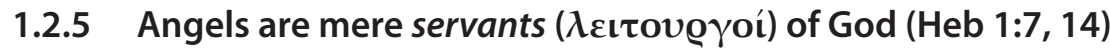

Angels serve God in different functions in Jewish literature: they are (a) angelic revealers or heavenly guides for those such as Enoch who visit heaven in apocalyptic 
visions; ${ }^{22}$ (b) they serve in a cultic capacity within the heavenly sanctuary, primarily praising God, ${ }^{23}$ but also "standing ${ }^{24}$ at his side and serving his will"; $; 2$ and they (c) serve as messengers or helpers of God to humanity. ${ }^{26}$

Early Jewish literature understood angels as mere "servants" of God. 1 Enoch speaks frequently of "the Lord of the Spirits"27 - which reminds strongly of the formulation

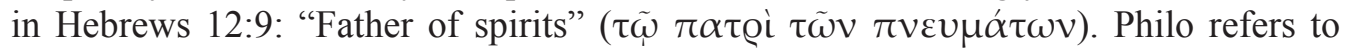

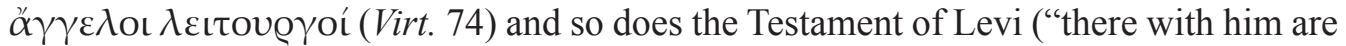
the archangels, who serve and offer propitiatory sacrifices to the Lord," T. Levi 3:5). In the quotation from Ps 103:4 (LXX) in Hebrews 1:7, it is particularly the $\lambda \varepsilon$ cเ who are made "flames of fire" - which should be understood in a cultic sense as the LXX versions use the term overwhelmingly in a cultic manner (Ellingworth 2000:132). It is then within this context that the author refers to the angels as "serving spirits"

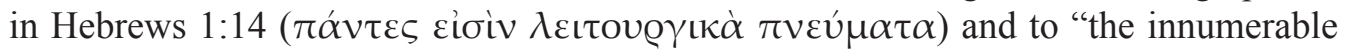

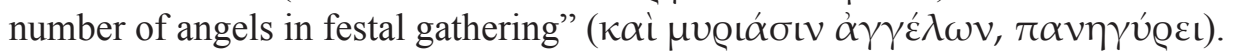

Turning to the NT, it is especially the Gospels that refer explicitly to the angels serving Christ ${ }^{28}$ but also the closing tone of Revelation itself: "It is I, Jesus, who sent my angel to you" (Rev 22:16). The divinity of Christ alongside God and exalted above the angels portrays an interesting relation between the NT Christology and angelology. The author of Hebrews drives this point home - especially in Hebrews 1-2 - with his powerful comparison between the nature and function of the angels in relation to Christ. The Son has been exalted to the most honorable position in the apocalyptic throne room of God. He sits as King and Judge on God's throne whilst the angels are serving them in cultic worship in the heavenly sanctuary. ${ }^{29}$

\subsubsection{Angels are God's Messengers to Humanity (Heb 2:2)}

The notion of the angels being used by God as messengers of God's message to humans on earth is common in early Judaism and early Christianity. ${ }^{30}$ The "message is declared through ${ }^{31}$ angels" ( $\alpha \gamma \gamma \varepsilon \dot{\lambda} \lambda \omega \nu \lambda \alpha \lambda \eta \theta \varepsilon i \varsigma$ ᄉó $\gamma \mathrm{O}$, , Heb 2:2) who communicated God's

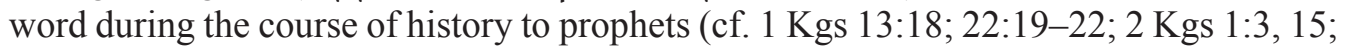
Isa 6; Jer 23:18, 23) (Watson 1992:249). It is the angels who became the communicators between God and humanity, bridging the gap between heaven and earth, often by taking anthropomorphic forms - a matter which Hebrews refers to (13:2).

The message referred to in Hebrews 2:2 is that of the Law of Moses. Scholars previously pointed out that the idea of angels who acted as intermediaries in the giving of the Law to Moses, is well attested in the $\mathrm{NT}^{32}$ and in Jewish tradition, ${ }^{33}$ suspecting, like many others, that "the belief is suggested by, and may have originated in Deuteronomy

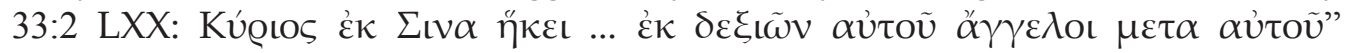
(Ellingworth 2000:137). In the book of Jubilees, ${ }^{34}$ for instance, "the halakah in that book was dictated to Moses by angels who read from the heavenly tablets" (Nickelsburg and Baltzer 2001:480). 


\subsubsection{Christ was made a little lower than the angels for a short while (Heb 2:7)}

Some differences between the LXX translation(s) and the Hebrew text include the Hebrew מעֵ ("a little lower") that was understood in a temporal sense and became

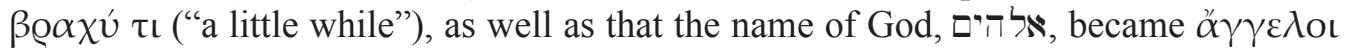

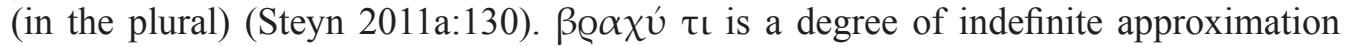
and may be translated with "somewhat" or "about" (Louw and Nida 1988:\$78.43). It

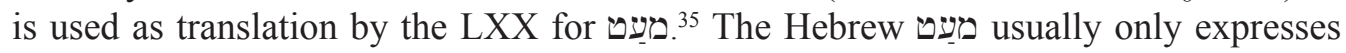
the qualitative meaning ("a little less"), whereas the LXX translation $\beta \mathrm{O} \alpha \chi v$ u $\tau$ is taken by the majority of scholars in a temporal sense ("a short while") (Harder 1939:35; Kistemaker 1961:30; Schröger 1968:82-83; Van den Brink 1993:206; Combrink 1971:29; Holwerda 2003:24; Moyise 2001:101; Schunack 2002:33). Some scholars, however, are of the opinion that there is a case to be made for the fact that $\beta \rho \alpha \chi u ́ s$ could be taken in both the LXX and in Heb 2:7 also in a qualitative sense, as in the Hebrew, so that man was made "a little lower than the angels" and not "a little while." Proponents of this position argue that both the MT and the LXX refer to degree rather than to time, as there is no hint of eschatological progression, and also that the change from a qualitative to a temporal meaning was then made by the author of Hebrews. ${ }^{37}$ The author comes back in his discussion on the quotation to this phrase, and it is especially in the light of his comments in 2:9 that it seems as if he intends the phrase to be taken in a temporal sense. He uses the word again in Heb 13:22, saying that he wrote only "a few" words, or "briefly."

The LXX uses $\ddot{\alpha} \gamma \gamma \varepsilon \lambda$ o as a translation for אלהים - that is, "a little lower than angels" ${ }^{38}$ rather than the Hebrew "a little lower than God / heavenly beings." ${ }^{39}$ The possible ambiguity in meaning (either "God" or "heavenly beings" / "gods"), swayed the LXX translators to the latter. The translators of the Greek LXX clearly made their choice here on theological grounds in order to differentiate between the God of Israel und subordinate divine beings (similarly Schenker 2001:191, 193). This interpretation is also to be found in Targum Jonathan (Kistemaker 1961:30; Van den Brink 1993:206). The "heavenly beings" were probably understood to be the members of the heavenly court, based on a Canaanite background (cf. Attridge 1989:71; Cooke 1964:22-47). The Greek texts thus speak of a humiliation in relation to the angels, while its Hebrew Vorlage argued about a "humiliation" in relation to God - but exactly this fits the concept of the author of Hebrews (Schröger 1968:83).

\section{A Festal Gathering of many Angels in the Heavenly Jerusalem (Heb 12:22)}

The event of receiving the law on Sinai during the old dispensation through the mediation of Moses, is now contrasted by the author of Hebrews with the event of those who gathered on Mount Zion, who arrived at the "congregation of the Firstborn." It is to be expected then, against the backdrop of this contrast between the old covenant 
and the new covenant, that a different interpretation of the Mosaic law would feature in the light of the Jesus-event. The divine revelation within the Jewish history is now being reinterpreted by early Christianity in terms of Christ. The setting presented in Hebrews is that of another "Mount Zion", another "Jerusalem" which is the "city of God" and a "heavenly" city, and another "congregation" - consisting of "innumerable

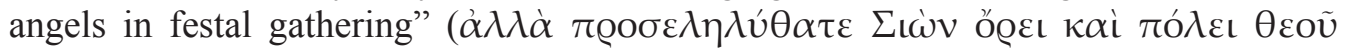

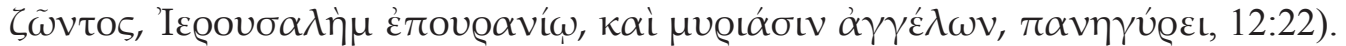
Superimposed on the imagery of the motif of receiving the law on Mount Sinai is the imagery of God as King in heaven with a host of angels serving him. The imagery reminds of 1 Kings 22:19 ("I saw the LoRD sitting on his throne, with all the host of heaven standing beside him to the right and to the left of him"), of Ezekiel 28:14 ("With an anointed cherub as guardian I placed you; you were on the holy mountain of God; you walked among the stones of fire"), and of 1 Enoch 40:1 ("And after that, I saw a hundred thousand times a hundred thousand, ten million times ten million, an innumerable and uncountable (multitude) who stand before the glory of the Lord of the Spirits"). Even more interesting is the description in 1QM 12.1-4: "For the multitude of the Holy Ones [is with Thee] in heaven..." "Thou wilt muster the [hosts of] Thine [el]ect, in their Thousands and Myriads, with Thy Holy Ones [and with all] Thine Angels..." (in Vermes 1977:139). Attention was already drawn to the fact that the literature of the Qumran community “....speaks of enjoying present communion with the angels as part of the blessedness of membership in the community of the new covenant (1QS 11.7-8; 1QSa 3.3-11; 1QH 3.21-22; 6.12-13; 11.10-14)" (Watson 1992:253).

Sharing now God's throne as King and Judge, Christ - the "Firstborn" - has extended the congregation of worshipers in Hebrews to include the believers alongside the angels: "but you have come to..." ( $\alpha \lambda \lambda \dot{\alpha} \pi$ @oo $\varepsilon \lambda \eta \eta \lambda \hat{v} \theta \alpha \tau \varepsilon, 12: 22)$. The recipients are "the assembly of the Firstborn who are enrolled in heaven" (Heb 12:23). ${ }^{40}$ There is an immediateness of Zion, of the heavenly Jerusalem and of the angels that have been reached. The believers on earth thus "already have access to the realm of heaven and to God's presence" $(4: 16 ; 10: 19,20)$ (Lincoln 2006:94) and might justifiably be seen as "Himmelsbürger auf Erden" (Backhaus 2004:219). "Through Jesus, Christians also have access to the throne of God and are able to go behind the curtain and enter in a spiritual sense this ultimate 'heaven' that is God's presence (Heb 10:19-22; 4:14-16). They have in this way a foretaste now of their final entrance into that unshakable heaven and divine rest (Heb 4:1, 11; 6:19-20)" (DeSilva 1997:n.p.).

The motif of the future "city of God" and its cultic connections surfaces strongly in the latter part of the book of Hebrews: Abraham was looking forward to the city with foundations, whose architect and builder is God (11:10). ${ }^{41}$ They were longing for a better country, a heavenly one ${ }^{42}$ and God has prepared a city for them (11:16). They have come to mount Zion, the heavenly Jerusalem, the city of the living God, to thousands upon thousands of angels in joyful assembly, to the church of the firstborn, whose names are written in heaven. They have come to God the Judge of all, to the spirits of righteous people made perfect, to Jesus the Mediator of a new covenant, and 
to the sprinkled blood that speaks a better word than the blood of Abel (12:22-24). They have an altar from which those who minister at the tabernacle have no right to eat (13:10). Jesus suffered outside the city gate to make the people holy through his own blood (13:12). Outside the camp they do not have an enduring city, but are looking for the city that is to come (13:14) (Steyn 2011a:269, 350; 2011 b).

Traces of the transition from Judaism to early Christianity would also become obvious in the celebration of the Jewish festivals. Hebrews portrays - within an apocalyptic context - a festal gathering during which cultic service takes place in the heavenly sanctuary. Furthermore, in his portrayal, it seems to be a common liturgical rite of Christian believers with the angels who are servants in God's sanctuary - now serving Christ as their Superior and as the "Firstborn" (Steyn:Forthcoming a) (cf. Heb 1-2 and Christ's superiority above the angels). The apocalyptic picture is clear: Hebrews' angelology does not point to angel worship, but to worship of Christ by the Christian believers together with the angels. Despite the fact that the angels ("sons of God") share the same heavenly realm as Christ ("Son of God"), they are found to be in a festal gathering, serving in the heavenly sanctuary (12:22), whereas Christ rules and judges from the throne on God's right hand. Similar to 1 Enoch 14, the picture of the heavenly world is drawn from both royal court imagery as well as temple imagery. Within this apocalyptic picture, "the angels may be described as priests who serve in the heavenly temple (Jub. 30:18; 31:14; T. Levi 3:5-6; 1QSb 4.24-26; Mas $1 k^{43}$, passim)" (Watson 1992:252). Mere speculation remains regarding the connection between this apocalyptic-eschatological worship with angels in a heavenly sanctuary and the reality of cultic worship on earth - especially in light of Hebrews' presentation of the earthly which is a mere "shadowy copy" of the heavenly. "The activity of the earthly tabernacle and cultus is a reflection and an extension of a heavenly temple and cultus where angels worship the one God" (DeSilva 1997:n.p.) - because access to God was made possible through worship (Ellingworth 2000:104).

\section{The characters of Moses and Melchizedek as angels?}

\subsection{Moses as an angel? (Heb 3:1-6)}

The fact that Moses held a high position in several Jewish groupings has been convincingly argued in scholarship (so, for instance, by Ellingworth 2000:194). Examples in this regard include Philo who repeatedly called him a "high priest" 44 and even refers a few times ${ }^{45}$ to him as $\theta \varepsilon$ ćs. The Samaritans referred to him with the title "Son of the house of God" which links him with the angelic dynasty where he was seen to be the highest among the angelic "sons of God" - mainly based on the tradition of Exodus 7:1 ("I make you as "elohim" to Pharaoh") (Fossum 1985:122, 123-29, 150-51; Fossum 1992:130). Palestinian Judaism stands in a similar tradition when the Hebrew text of Sirach states that "God magnified Moses as a god" (Sir 45:2) - a legend that continues 
in the Assumption of Moses. In the rabbinic tradition, Moses was even seen to hold a higher status than that of the angels (cf. D'Angelo 1979:95). Ellingworth reckons that "It is not necessary to claim that the author of Hebrews was directly influenced by any of these texts, but they illustrate what may, in some form, have been the presuppositions of the author and of his readers concerning Moses, who was "for later Judaism the most important figure in salvation history thus far" (Ellingworth 2000:194).

Similar traditions about Moses as an angel-like figure probably had their origins, on the one hand, in Exodus 34:29-35 where mention is made about Moses' angel-

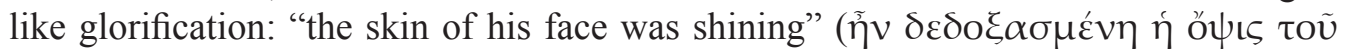

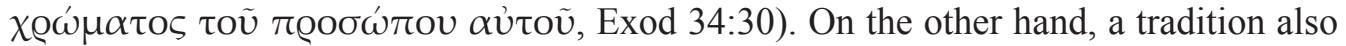
existed that the angels acted as mediators when the Law was given to Moses on Sinai. Traces of the latter tradition are particularly found in Galatians 3:19, Acts 7:53 and Hebrews 2:2. There is also an interesting resemblance in this regard with the revelation of Jubilees where "the angel of the presence" reveals almost all of that book to Moses, (VanderKam 2000:n.p.) instructing Moses about everything "from the beginning of creation until my sanctuary has been built among them for all eternity" (Jub. 1:27) (VanderKam 1992:1030.)

The author of Hebrews presents Jesus now as "worthy of more glory than Moses"

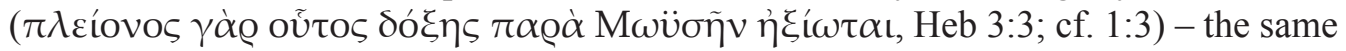
Moses who was another potential mediating figure alongside the angels. The metaphor of the "house of God" is now used and reminds of the OT concept of Israel as the household of God. The author argues that the builder of a house deserves greater honour than the house itself. Whereas Moses on the one hand serves in the house as a servant, as a $\theta \varepsilon \rho \alpha ́ \alpha \omega \nu$ - a term which contained cultic and prophetic elements and that was used for the priests of Asclepius and for the servants of the Pharao - Christ on the other hand, is over the house as the Son of God. Moses' honor is thus inferior to that of God who built the house and particularly to that of Jesus as God's Son. The "house" is explained in Hebrews 3:6 in terms of the community of believers: "we are his house." Ellingworth points to the fact that "apocalyptic and rabbinic usage suggests that God's house was thought of as a community embracing not only human but also angelic beings" (Ellingworth 2000:196) - an observation which, in turn, immediately reminds of the festal worshiping community of believers and angels in Hebrews 12.

\subsection{Melchizedek as an angel? (Heb 7)}

Melchizedek was no unknown motif in the Jewish literature. Various speculations were made about this mysterious person through the ages (cf. Delcor 1971:115-135; Steyn 2002:207-223). Amongst the Dead Sea Scrolls, especially the remains of an eschatological Midrash, known as the Melchizedek Document (11QMelch), sheds light on some of these traditions. Its central motif "is the expectation of the coming of Melchizedek as the Heavenly Judge in the Last Judgment" (Flusser 1988:186 [see p.187 for a reprint of the text]). According to 1QM 17:7-8, God will send the archangel 
Michael to deliver Israel: "[God] will raise up the kingdom of Michael among the gods [that is, angels] and the realm of Israel in the midst of all flesh." Although Melchizedek and the archangel Michael are never explicitly equated in the Qumran literature, we find Melchizedek pictured here as being identical with the archangel Michael. He is the deliverer and the chief of the heavenly beings (literally 'gods', elohim) (Vermes 1977:82, 184). 11QMelch pictures Melchizedek as "captain of the host of heaven, suggesting that he is to be numbered among the archangels", and as a seated judge, like Moses, on a throne of glory, "exercising judgment over the destinies of men" (Russel 1987:43). The same similarity between the roles of Melchizedek and the archangel Michael is also to be found in the War Scroll (1QM 9.14-16). It has been suggested that Melchizedek may be identified with the "Son of God" in the Aramaic Apocalypse ("Son of God" 4Q246) (Schniedewind 2000:n.p.). Flusser has a similar suspicion that there could have been a contamination between the two personages - Melchizedek as a mythical figure and as the Son of Man (Flusser 1988:191). Along the same lines Vermes is of the opinion that Melchizedek was probably also to be identified with the "chief of the Sons of Light" in the Testament of Amram (4QAmram) (Vermes 1977:70). The elements of Melchizedek being ruler of the host of heaven, judge or possibly "chief of the Sons of light" do not fit those in Hebrews 7:1-4. The closest might be if Martinez' suggestion that "son of God" in 4Q246 refers to Melchizedek, and if "son of God" is then identified to be the "king", as in Hebrews 7:1-2. But such an argument would be built on too many presuppositions, on the one hand, and there would be too many remaining elements in Hebrews 7:1-4 that are not found in the Qumran literature.

\section{$4 \quad$ Hospitality to angels (Heb 13:2)}

Deuteronomy honours and protects the position of strangers or aliens $(10: 18-19 ; 24: 17$; $25: 5 ; 27: 19)$. Josephus takes a similar position on hospitality (Ferguson 1993:457) - and

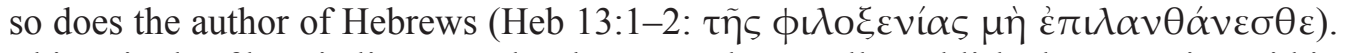
This attitude of hospitality towards others was also a well-established expectation within the early Christian tradition. ${ }^{46}$ Apart from Hebrews 13:2, it is also used in Romans 12:13 and again within a paraenetic context (Balz and Schneider 1993:427). The same moral expectation is noticeable in other early Christian intertexts, such as in Romans 16:33; 1 Timothy 3:2; Titus 1:8; 1 Peter 4:9; 2 John 10; 3 John 5-8; 1 Clement 10-12 and Didache 11-13 (cf. Steyn 2010:318).

\section{Conclusion}

It has become clear that the author of Hebrews has a complex and more developed understanding of angels. Firstly, in the first two chapters of Hebrews, the author presents a "high" Christology where the readers encounter the exalted Son of God at the most honourable position on the throne, next to the right side of God in the throne room of heaven where he rules with God as King and Judge - a position given to him by God 
himself. This Son's position and Name differs, however, from the other "sons of God," i.e. the angels. They do not rule with God, but have an inferior position, inferior roles and inferior names. They are mere servants, winds, flames and messengers of God. The fact of Christ's humiliation to come to earth and suffer here should be understood in perspective, according to the author of Hebrews. This was only for a short while that he was made a little lower than the angels. He now rules whereas the angels are still carrying out their same duties through the aeons as servants of God.

Secondly, one might probably place the perception of Moses as a "son of God" and Melchizedek who was possibly perceived as the archangel Michael in some circles of early Judaism, alongside the position ascribed to angels by the author of Hebrews. If

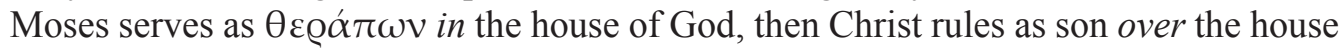
of God. Hebrews' angelology is thus clearly subordinate to his Christology - a picture which becomes even clearer against the backdrop of the position of angels in the early Jewish apocalyptic world.

Thirdly, in the latter part of Hebrews the early Christian believers find themselves present with the angels in the throne room of God. It is a cultic festival gathering on Mount Zion and in the heavenly Jerusalem where God is worshiped by both angels and earthly believers who now jointly form the "congregation of the Firstborn."

Fourthly, the final chapter of Hebrews appeals to the early Christian believers to be hospitable. The appeal is rooted in the belief of the visitation of angels amongst humans in an anthropomorphic form which makes them unrecognizable to humans. This anthropomorphic form of angels serves as a rhetorical device to appeal to the readers to be hospitable to strangers - probably based on the narrative of the three men who visited Abraham and turned out to be angels. This argument completes the circle of relations between Christ, the angels and humans in Hebrews: Christ occupies the ultimate position in heaven and the angels are subordinate to him. Angels are nonetheless of a higher rank than humans, being the messengers of God. But believers find themselves also worshiping the Son alongside the angels.

\section{NOTES}

1 "The formal unity of Part I is marked by the mention of angels in 1:5 and 2:16, a typical inclusio." (Ellingworth 2000:107).

2 For a detailed exposition on "Angelic Revelation in Jewish Apocalyptic Literature," see S. Beyerle (2007:205-223).

3 Similarities between the ideas of the Songs of the Sabbath Sacrifice and Hebrews have been noticed by scholars before. Cf., for instance, Morray-Jones (1998:178) who states that these themes were "taken up and developed in combination by the Christian writers, who regarded their Savior-Messiah as 'a great high priest who has gone through the heavens (Heb 4:14)"'. So also Gäbel (2006:60-69) and Steyn (2011a:193; Forthcoming a).

41 Enoch predates the NT: $2^{\text {nd }}$ century B.C.E. to $1^{\text {st }}$ century C.E. (Isaac 1983:5). Cf. C. Wassen for an overview of angels in the Dead Sea Scrolls (2007:499-524). 
5 Cf. Newsom: "It is difficult to say with certainty whether the Sabbath Songs were composed by the Qumran community. The presence of one copy at Masada [Mas1k] and the use of אל הים as a divine name (avoided in other Qumran sectarian literature) could indicate a pre-Qumran origin for the text. Whether that is the case or not...the Songs of the Sabbath Sacrifice were highly influential at Qumran. The content of the material makes it likely that the Sabbath Songs were composed for a group with a strong priestly identity" (1992:155).

6 Due to many similarities, some scholars found dependence of Ps 104(103) upon the great Egyptian Sun Hymn from Tell al-Amarna, a hymn to the sun god Atum, Aten or Re by the Pharaoh Akhenaton.

7 Ps 104(103) was probably used during the Jewish synagogue liturgies on Friday evenings and Sabbath mornings (Kistemaker 1961:23; 1984:41; Werner 1959:150). In the early Christian period Ps 104(103) was traditionally used on Ascension Day from the earliest days of the Christian Church (Vos 2005:249-250).

8 Cf. Ellingworth (2000:121). Attridge argues similarly: "The translator of the LXX may have had in mind theophanies in which meteorological phenomena were taken to be transformed angels" (1989:58).

9 See the more extensive discussion on this issue by Rüsen-Weinhold (2004:178-179).

10 The Hebrew מלאן can also mean "angel” (cf. Holladay 1980:196; Jastrow 1950:786). This is also the word that is usually translated with $\ddot{\alpha} \gamma \gamma \varepsilon \lambda$ o s by the LXX translators, including the Psalms (except for Pss 8:5; 77:25; 96:7; 137:1). Cf. Hatch and Redpath 1975:7-9.

11 Schröger formulates too strong when he says that "Im masoretischen Text steht in diesem Psalm überhaupt nichts über die Engel" (1968:57).

12 Ellingworth argues, however, that the LXX cannot mean "who makes his angels into winds," but rather "who makes winds his messengers" (2000:120).

13 Schunack, in turn, says: "Die Engel sind wandelbare Diener..." (2002:27).

14 “'Spirit' (רות or $\pi v \varepsilon \tilde{v} \mu \alpha$ ) is increasingly used in later Jewish writing for angels or demons (usually in the plural) at Qumran and in rabbinic and apocalyptic literature" (Paige 1997:n.p.).

15 Cf., for instance, Plato Theaet 201e and Diogenes Laertius 7.136, 137. Similar also in Jewish literature 2 Macc 12:13 and Wis 7:17.

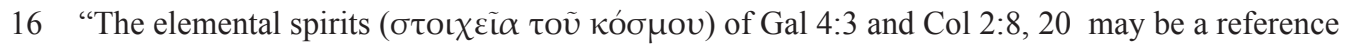
to demonic angels ruling the world (Watson 1992:254).

17 Cf. PGM XV. 14, 16 (Preisendanz).

18 Manuscripts B and C read the singular here - probably intending Uriel, "the flame of God."

19 "According to Dan 12:3 the risen shall shine 'like the stars forever and ever' (cf. the use of 'stars' for angels in Dan 8:10)" (Meyer 1992:792).

20 The righteous "shall be made like the angels and be made equal to the stars [italics mine]; and they shall be changed into whatever form they will" (Collins 2000: n.p.).

21 Nickelsburg and Baltzer (2001:181) refer to Black who drew attention to "the stars of 'El" in Isa $14: 13$. The plural, which is a remnant from the old Canaanite myth, suggests a generic meaning (1970:120).

22 Cf. Dan 7-12; 1 En 17-36; Apoc. Ab. 10-18; 4 Ezra 3-14 (Watson 1992:252).

23 "They worship him as members of his court (Dan 7:10)" (Davidson 1992:8). "In Jubilees the angels of the presence and the angels of holiness observe the Sabbath and the Feast of Weeks and 
are said to have been created circumcised (Jub. 2:17-18; 6:18; 15:27)" (Watson 1992:252).

24 "Standing was the normal position of the priest exercising his cultic functions (cf. 2 Sam [LXX 2 Kgdms.] 8:11; 13:1; Jer 28 [LXX 35]:5; 44:15; Josephus, Ant. 13.372); it was also the position of angels in the heavenly court (Lev 1:19; Isa 6:5; Rev. 7:11; Heb 1:3)" (Ellingworth 2000:507).

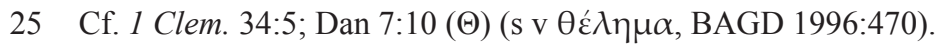

26 E.g., Dan 6:22. For examples of angelomorphic appearances in ancient literature, see Steyn 2003. They “... serve him by intervening in human affairs, bringing divine messages (Gen 22:11-12)" (Davidson 1992:8).

27 Cf. 1 En 40:5; 41:2, 6-8; 43:4; 46:8; 47:2, 4; 48:2, 5, 7, 10; 57:3; 58:4; 68:4; 69:25.

28 Cf. Matt $4: 6 ; 11 ; 13: 41 ; 16: 27 ; 26: 53$; Luke 2:13; 4:10.

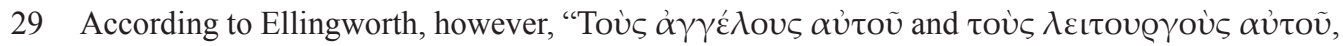
following $\alpha$ $\gamma \gamma \varepsilon \lambda$ o $\theta \varepsilon \delta \tilde{v}$ in v. 6, are most naturally understood as God's angels or servants, rather than the angels or servants of the Son" (2000:120).

30 "Angels can dwell in heaven (Matt 18:10; Mark 12:25) and move freely between heaven and earth (Matt 28:2; Luke 2:13; John 1:51)" (Davidson 1992:9).

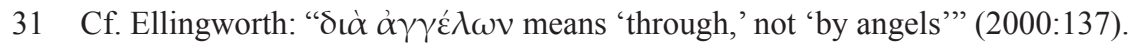

32 Cf. also Acts 7:38, 53; Gal. 3:19. (Ellingworth 2000:138). So too, Watson 1992:254.

33 Jub. 1:27; 2:1, 26; Josephus, Ant. 15.5.3; also at Cairo (CD 5.18; Braun 1966:245).

34 See Jub. 3:31; 6:17, 35; 16:18-29; 18:19; 23:32; 30:19; 31:32; 32:15.

35 So also at $2 \mathrm{Kgdms}$ 16:1 and Isa 57:17. $\beta \varrho \alpha \chi u ́$ itself is exclusively used as translation equivalent for except once in Exodus.

36 Louw and Nida support this interpretation in saying that the expression $\beta \varrho \alpha \chi v \in$ $\tau \iota$ as a lexical unit in Heb 2:7 refers to rank (1988:Domain 78.43).

37 So Kistemaker 1961:30. Pryor found several indications "that the author has chosen to give this phrase a temporal meaning which it may not have had originally" (1981:44-45). This standpoint is also confirmed by Louw and Nida who reckon that Heb 2:8-9 "...suggests that the writer of Hebrews probably interpreted $\beta \mathrm{e} \alpha \chi u$ as meaning a small quantity and as referring to time in the sense of a 'little (while)"' (1988:\$78.43).

38 Attested by the Psalterium Gallicanum of Jerome and Codex a. "Hieronymus hat G [Psalterium Gallicanum] entsprechend mit angelis, seine hebräische Vorlage aber mit a Deo übersetzt" (Kaiser 1994:208). Also the Coptic version has "angels" here.

39 The later versions of Aquila, Symmachus and Theodotion, would again translate $\theta \varepsilon o ́ s$.

40 The similarity with $J u b$. 2:10 might be helpful in understanding this as Jewish Christians who are addressed “....worum sie als Angehörige Israels, des 'erstgeborenen Sohnes Gottes'...in besonderer Weise wissen dürfen” (Stuhlmann 1983:143).

41 Similar imagery is to be found in 1QH 6:24-26; Sib V 250f.; 1 En 90:29 and Rev 21:10. See Fischer 1978:117-118.

42 Lincoln has drawn attention to the "heavenly" terminology: "a heavenly call (3:1), the heavenly gift (6:4), the heavenly sanctuary (8:5), the heavenly things (9:23), a heavenly country $(11: 16)$ and the heavenly Jerusalem (12:22)" (2006:95).

43 Sir ̌̌ $a b b$ 
44 Cf. Her. 182; Sacr. 130; Mos. 1.334, 2.2-7, 66ff., 153-158, 187, 275.

45 E.g., Mos. 1.158; Somn. 2.189.

46 Ferguson summarises the important place that hospitality occupied in early Christianity, as "the needs of missionaries and messengers of the churches provided an extended family, giving lodging and assistance for the journey. Christians here followed and expanded a Jewish practice of caring for their own when away from home (cf. Mark 6:10). Many synagogues had guest rooms attached for the use of Jews on a journey" (Ferguson 1993:82).

\section{BIBLIOGRAPHY}

Alexander, P. 1983. 3 (Hebrew Apocalypse of) Enoch. In OTP. Vol. 1. Edited by C. H. Charlesworth, 223-315. Doubleday, New York.

Arndt, W., F. W. Gingrich, F. W. Danker and W. Bauer (eds.). 1996. A Greek-English lexicon of the New Testament and other early Christian literature. 2nd ed. University of Chicago, Chicago.

Attridge, H. W. 1989. The Epistle to the Hebrews. Hermeneia. Fortress, Philadelphia.

Backhaus, K. 2004. Gott als psalmist: Psalm 2 im Hebräerbrief. In Gottessohn und Menschensohn. Edited by D. Sänger, 198-231. Biblisch-Theologische Studien 67. Neukirchener Verlag, Neukirchen.

Balz, H. and G. Schneider (eds.). 1993. EDNT. Vol. 3. Eerdmans, Grand Rapids.

Beckwith, R. T. 2005. Calendar, chronology and worship: Studies in ancient Judaism and early Christianity. Brill, Leiden.

Beyerle, S 2007. Angelic Revelation in Jewish Apocalyptic Literature. In Deuterocanonical and cognate literature: Yearbook 2007. Angels. The Concept of Celestial Beings: Origins, developments and reception. De Gruyter, Berlin.

Black, M. (ed.). 1970. Apocalypsis Henochi Graece. PVTG 3. Brill, Leiden.

Braun, H. 1966. Qumran und das Neue Testament I-II. Mohr Siebeck, Tübingen.

Bruce, F. F. 1985. The Epistle to the Hebrews. NICNT. Eerdmans, Grand Rapids.

Collins, J. J. 2000. s v. Eschatologies of late antiquity. In DNTB.

Collins, J. J. 1993. Daniel. Hermeneia. Fortress, Minneapolis.

Combrink, H. J. B. 1971. Some thoughts on the Old Testament citations in the Epistle to the Hebrews. Ad Hebraeos: Essays on the Epistle to the Hebrews. Neot 5:22-36.

Cooke, G. 1964. The Sons of (the) God(s). ZAW 76:22-47.

D’Angelo, M. R. 1979. Moses in the Letter to the Hebrews. SBLDS 42. Scholars Press, Missoula.

Davidson, M. J. 1992. s v. Angels. In DJG. Edited by J. B. Green, S. McKnight and I. H. Marshall, 8-11. InterVarsity, Downers Grove.

Delcor, M. 1971. Melchizedek from Genesis to the Qumran texts and the Epistle to the Hebrews. JSJ 2:115-135.

DeSilva, D. A. 1997. s v. Heaven, new heavens. In DLNT. Edited by R. P. Martin and P. H. Davids. Electronic ed. InterVarsity, Downers Grove.

Ellingworth, P. 2000. The Epistle to the Hebrews. NIGTC. Eerdmans, Grand Rapids.

Evans, C. A. and S. E. Porter (eds.). 2000. DNTB. Electronic ed. InterVarsity, Leicester. 
Ferguson, E. 1993. Backgrounds of Early Christianity. Eerdmans, Grand Rapids.

Fischer, U. 1978. Eschatologie und jenseitserwartung im hellenistischen Diasporajudentum. De Gruyter, Berlin.

Flusser, D. 1988. Melchizedek and the Son of Man. In Judaism and the Origins of Christianity. Edited by D. Flusser, 189-192. Magnes, Jerusalem.

Fossum, J. E. 1985. The Name of God and the angel of the Lord. WUNT. Mohr Siebeck, Tübingen.

Fossum, J. 1992. s v. Son of God. In ABD. Vol. 6. Edited by D. N. Freedman, 6 vols, 128-137. Doubleday, New York.

Gäbel, G. 2006. Die Kulttheologie des Hebräerbriefes. WUNT 2/212. Mohr Siebeck, Tübingen.

Gäbel, G 2007. "Rivals in Heaven: Angels in the Epistle to the Hebrews", 357-376, in Reiterer, F.V; Nicklas, T \& Schöpflin, K (eds), Deuterocanonical and Cognate Literature: Yearbook 2007. Angels. The Concept of Celestial Beings - Origins, Development and Reception. Berlin/New York: De Gruyter.

Grässer, E 1965. Der Glaube im Hebräerbrief. Elwert, Marburg.

Grässer, E. 1990. An die Hebräer. 1. Teilband, Hebr 1-6. EKK 7/1. Benziger Verlag, Zürich.

Guthrie, G. H. 2004. Hebrews in its first-century contexts: Recent research. In The Face of New Testament Studies: A survey of recent research. Edited by S. McKnight and G. R. Osborne, 414-443. Baker, Grand Rapids.

Harder, G. 1939. Die Septuagintazitate des Hebräerbriefes. In Theologia Viatorum: Theologische Aufsätze. Edited by M. Albertz und H. Asmussen et al, 33-52. Kaiser, München.

Hatch, E. and H. A. Redpath 1975. A Concordance to the Septuagint, vol. 1: A-I. Akademische Druck- u. Verlagsanstalt, Graz.

Holladay, W. L. 1980. A Concise Hebrew and Aramaic lexicon of the Old Testament. Eerdmans, Grand Rapids.

Holwerda, D. 2003. Hebreeёn. Kok, Kampen.

Isaac, E. 1983. 1 (Ethiopic Apocalypse of) Enoch. In The OTP, vol. 1. Edited by C. H. Charlesworth, 5-89. Doubleday, New York.

Jastrow, M. 1950. A Dictionary of the Targumim, the Talmud Babli and Yerushalmi, and the Midrashic Literature, vol. 2: $\Omega-$ ל. Pardes, New York.

Kaiser, O 1994. Erwägungen zu Psalm 8. In „Neue Wege der Psalmenforschung “: Für W. Beyerlin. Edited by K. Seybold and E. Zenger, 207-221. Herders Biblische Studien 1. Herder, Freiburg.

Karrer, M. 2006. The Epistle to the Hebrews and the Septuagint. In Septuagint research: Issues and challenges in the study of the Greek Jewish Scriptures. Edited by W. Kraus and R. G. Wooden, 335-353. SBL 53. SBL, Atlanta.

Karrer, M. 2002. Der Brief an die Hebräer. Kapitel 1,1 - 5,10. ÖTK 20/1. Gütersloher Verlagshaus, Gütersloh.

Käsemann, E. 1961. Das wandernde Gottesvolk: Eine untersuchung zum Hebräerbrief. FRLANT 55. Vandenhoeck \& Ruprecht, Göttingen.

Kistemaker, S. 1961. The Psalm citations in the Epistle to the Hebrews. W. G. van Soest, Amsterdam.

Kistemaker, S. J. 1984. New Testament commentary. Exposition of the Epistle to the Hebrews. Baker, Grand Rapids. 
Knibb, M. A. 1978. The Ethiopic book of Enoch: A new edition in the light of the Aramaic Dead Sea fragments, vol. 2. Clarendon, Oxford.

Lane, W. L. 1998. Hebrews 1-8. WBC 47A. Word, Dallas.

Lincoln, A. 2006. Hebrews: A Guide. Continuum, London.

Louw, J. P. and E. A. Nida. 1988. Greek-English lexicon of the New Testament: Based on semantic domains, 2 vols. United Bible Societies, New York.

McLay, R. T. 2003. The Use of the Septuagint in New Testament research. Eerdmans, Grand Rapids.

McLay, R. T. 2006. Biblical Texts and the Scriptures for the New Testament church. In Hearing the Old Testament in the New Testament. Edited by S. E. Porter, 38-58. Eerdmans, Grand Rapids.

Meyer, B. F. 1992. s v. Jesus. In $A B D$. Vol 3. Edited by D. N. Freedman, 6 vols., 773-796. Doubleday, New York.

Milik, J. T. 1976. The Books of Enoch: Aramaic Fragments of Qumrân Cave 4. Clarendon, Oxford.

Morray-Jones, C. R. A. 1998. The Temple within: The embodied divine image and its worship in the Dead Sea Scrolls and other Jewish and Christian sources. SBL Supplement Series 37:400-431.

Moyise, S. 2001. The Old Testament in the New: An introduction. Continuum, London.

Newsom, C. A. 1992 s v. Songs of the Sabbath Sacrifice. In $A B D$. Vol. 6. Edited by D. N. Freedman, 6 vols, 155-156. Doubleday, New York.

Nickelsburg, G. W. E. and K. Baltzer 2001. 1 Enoch: A commentary on the book of 1 Enoch. Fortress, Minneapolis.

Paige, T 1997. Spirits. In DLNT. Edited by R. P. Martin and P. H. Davids. Electronic ed. InterVarsity, Downers Grove.

Preisendanz, K. (ed.). (1973-4). Papyri Graecae Magicae, 2 Bände. 2. Aufl.: A. Henrichs. Teubner, Stuttgart.

Pryor, J. W. 1981. Hebrews and Incarnational Christology. RTR 40/2:44-50.

Rüsen-Weinhold, U. 2004. Der Septuagintapsalter im Neuen Testament: Eine textgeschichtliche untersuchung. Neukirchener Verlag, Neukirchen.

Russell, D. S. 1987. The Old Testament pseudepigrapha. Fortress, Philadelphia.

Schenke, H.-M. 1973. Erwägung zum rätsel des Hebräerbriefes. In "Neues Testament und Christliche Existenz”: Festschrift für H. Braun. Edited by H. D. Betz and L. S. Betz, 421-437. Mohr Siebeck, Tübingen.

Schenker, A. 2001. Götter und engel im Septuaginta-Psalter: Text- und religionsgeschichtliche ergebnisse aus drei textkritischen untersuchungen. In Der Septuaginta-Psalter: Sprachliche und theologische Aspekte. Edited by E. Zenger, 185-195. Herders Biblische Studien 32. Herder, Göttingen.

Schniedewind, W. M. 2000. s v. Traditions of Melchizedek. In DNTB.

Schröger, F. 1968. Der Verfasser des Hebräerbriefes als Schriftausleger. Biblische Untersuchungen 4. Friedrich Pustet, Regensburg.

Schunack, G. 2002. Der Hebräerbrief. ZBK. Theologischer Verlag, Zürich.

Steyn, G. J. 2000. A quest for the Vorlage of the Song of Moses (Dt 32) quotations in Hebrews. Neot 34/2:263-272.

Steyn, G. J. 2001. “Jesus-Sayings” in Hebrews. ETL 77/4:433-440. 
Steyn, G. J. 2002. The Vorlage of the Melchizedek phrases in Heb 7:1-4. APB 13:207-223.

Steyn, G. J. 2003. Addressing an angelomorphic christological myth in Hebrews? HvTSt 59/4:1107-1128.

Steyn, G. J. 2007. Deuteronomy in Hebrews. In Deuteronomy in the New Testament. Edited by S. Moyise and M. M. J. Menken, 152-168. T\&T Clark, London.

Steyn, G J. 2010. Some possible intertextual influences from the Jewish Scriptures on the (moral) language of Hebrews. In The Moral language of the New Testament. Edited by J. G. van der Watt and R. Zimmermann, 311-329. WUNT. Mohr Siebeck, Tübingen.

Steyn, G. J. 2011a. A quest for the assumed Septuagint Vorlage of the explicit quotations in Hebrews. FRLANT. Vandenhoeck \& Ruprecht, Göttingen.

Steyn, G. J., Forthcoming a. The Eschatology of Hebrews as understood within a cultic setting. In Eschatology in the New Testament. Edited by J. G. van der Watt.

Steyn, G. J., 2011b. "On earth as it is in heaven...": The heavenly sanctuary motif in Heb 8:5 and its textual connection with the "shadowy copy" of LXX Exod 25:40". HvTSt 67/1.

Theissen, G. 1969. Untersuchungen zur Hebräerbrief. SNT 2. Mohn, Gütersloh.

Thompson, J. W. 1981. The beginnings of Christian philosophy: The Epistle to the Hebrews CBQMS 13. Catholic Biblical Association of America, Washington.

Van den Brink, G. 1993. "De schrift zegt of de schrift fantaseert?" (1) De tekst van oudtestamentische citaten in Hebreeën. In Bijbel en Exegese. Verkenningen in de katholieke brieven en Hebreeën. Edited by A. G. Knevel, M. J. Paul and P. H. R. van Houwelingen, 203-210. Theologische Verkenningen 7. Kok Voorhoeve, Kampen.

Van den Brink, G. 1993. "De schrift zegt of de schrift fantaseert?" (2) Het gebruik van het Oude Testament in Hebreeën," In Bijbel en Exegese. Verkenningen in de katholieke brieven en Hebreeën. Edited by A. G. Knevel , M. J. Paul and P. H. R. van Houwelingen, 211-217. Theologische Verkenningen 7. Kok Voorhoeve, Kampen.

VanderKam, J. C. 1992. s v. Book of Jubilees. In $A B D$. Vol. 3. Edited by D. N. Freedman, 6 vols, 1030-1032. Doubleday, New York.

VanderKam, J. C. 2000. s v. Jubilees. In DNTB.

Vermes, G. 1977. The Dead Sea scrolls: Qumran in perspective. Collins, London.

Vos, C. J. A. 2005. Theopoetry of the Psalms. Protea, Pretoria.

Wassen, C 2007. "Angels in the Dead Sea Scrolls". In Deuterocanonical and cognate literature: Yearbook 2007. Angels. The concept of celestial beings - Origins, development and reception. De Gruyter, Berlin.

Watson, D. F. 1992. s v. Angels. In $A B D$. Vol. 1. Edited by D. N. Freedman, 6 vols, 248-255. Doubleday, New York.

Werner, E. 1959. The sacred bridge. D. Dobson, London.

Williamson, R. 1975-76. The background to the Epistle to the Hebrews. ExpTim 87:232-237.

Wilson, J. M. 1930. Angel. In ISBE. Vol. 1. Edited by J. Orr, 132-135. Howard-Severance, Chicago.

Wise 2000. Dead Sea Scrolls: General Introduction. In DNTB. Edited by C. A. Evans and S. E. Porter. Electronic ed. Leicester: InterVarsity, Leicester. 